\title{
The Promise of Legal Semiotics
}

\author{
Sophie Cacciaguidi-Fahy · Annabelle Mooney
}

\begin{abstract}
The aim of the 2008 Roundtable was to focus on the progress to date in the many facets - methodological, epistemological and conceptual —of the field of legal semiotics, specifically the contribution of different schools and forms of semiotics as well as emerging and emergent semiotics approaches which can be used in researching and interpreting law and legal phenomena. The participants sought primarily to engage with the epistemological and methodological challenges which the field currently faces and to discuss the implications of these.
\end{abstract}

Keywords Law - Semiotics · Jurisprudence - Rhetoric · Meme · Interpretation $\cdot$ Science

\section{Introduction}

Many believe that for law to fully achieve its own vision, it requires a collateral discipline:

What do other disciplines think of law? Since it dropped its pretence to discreteness, like a mendicant has wandered round the corridors of academe seeking first succour here and there. It was nearly a century ago that it tried sociology, and since then it has sought support in a variety of disciplines [...]. [2, 10]

S. Cacciaguidi-Fahy $(\square)$

National University of Ireland, Galway, Ireland

e-mail: sofiecacciaguidi@eircom.net

A. Mooney (ه)

Roehampton University, London, UK

e-mail: A.Mooney@ roehampton.ac.uk 
In 1991 Jack Balkin and Jeremy Paul engaged in a debate published in the Texas Law Review on the conceptual nature and function of legal semiotics, namely "the value of the semiotic enterprise, and the future promise of legal semiotics" as a rigorous method of intellectual inquiry [1, p. 1831]. Balkin in his response concurred with Paul that "semiotic study is valuable for its own sake because it teaches us more about our legal culture" (ibid); and that "like deconstruction, semiotics has no necessary politics, but only the politics of those who make use of it" (ibid, p. 1832), while disagreeing on the fact that there "is little or no connection between semiotics and progressivism".

In convening the 2008 International Roundtable for the Semiotics of Law, we sought to reach back into the heritage of legal semiotics and to bring it together with the new direction which has taken place in the last decade. In doing so, we had hoped to rejuvenate a climate for shared insights in which emerging directions could be imbued with the intellectual rigour of the iconic minds which informed the early days of the legal semiotic movement. The articles selected by the International Journal for the Semiotics of Law for this Special Issue aspire to represent this programme while recognising the need for the field of legal semiotics to now move forward in a more authentic scholarly space.

With this in mind, the overall aim of the 2008 Roundtable was to focus on the progress to date in the many facets-methodological, epistemological and conceptual — of the field of legal semiotics, specifically the contribution of different schools and forms of semiotics as well as emerging and emergent semiotics approaches which can be used in researching and interpreting law and legal phenomena. We sought primarily to critically engage with the epistemological and methodological challenges which the field currently faces and to discuss the implications of these.

\section{The Promise of Legal Semiotics}

It is an impossible task in such a limited space to trace the historiography of legal semiotics and critically assess its impact on the study of law and the development of legal ideology (for a study on the tradition of law and semiotics, see [8, 9, 13, 12]; for a recent review of Peirce and Kevelson's work, see [16]).

José Sousa e Brito examines the work of Duncan Kennedy, including the argument that judges do not differ from legislators in their decision making. The Promise, here, is approaching legal science as a science, to reconstruct jurisprudence with this in mind. What is particularly enjoyable about this thought provoking reflection is its inception, that it began with a conversation with a student. It is in such ongoing conversations that the promises in the field of legal semiotics are made and kept.

Sousa e Brito explores the conventionally uncivilised in the motif of cannibalization. The idea of cannibalizing may well be conceived of in post-modern terms of bricolage as the author points out, comparing it to Balkin's 'rhetorization' and Derrida's 'reconstruction'. But as Balkin notes, this does not impede a claim to authenticity [1, p. 1845]. The cannibalizing, however, is somehow less civilized than 'philosophical critique', a distinction between the two that is elegantly made by Sousa e Brito. 
The central area of concern for his inquiry is jurisprudence, which he takes to mean both adjudication and legal doctrine. The former "determines the rule of the case and applies it to the case". The latter "determines what the rule of the case is according to the best legal opinion and determines the rules and principles that it finds in the sources or constructs from them and on which base the rule of any case should be determined". They are both normative, an important point as Kennedy argues that there is 'rightness' in legal argumentation. However, Sousa e Brito points out the paradoxical nature of the argument. If you do not believe in rightness of any kind, it becomes impossible to demonstrate your argument. In this way, one can read Sousa e Brito as cannibalizing Kennedy but in a very civilised way as he judges Kennedy's work "in its best form". While there are gaps in the law, these can be filled by such things as analogy and general legal principles. This does not always produce a single solution. Further, decisions can be overruled. As Sousa e Brito puts it, the judge has "the duty to give the one right answer". What sets the limits of this rightness is "the possible meaning of the words of a given law".

This brings us directly to the relevance of semiotics. Of particular note is the exploration of Llewellyn's canons for interpretation of statutes, which is an excellent example of semiotics in action. As Sousa e Brito argues, the "argumentbites" do not bite as there is no discretion in the choice between them.

A semiotic analysis that sets its limits not only within the possible meaning of the words but also within the possible and practical spheres of action is well suited to the law. That ethics emerges from this approach is an entirely appropriate development. These papers demonstrate that the analysis of legal discourse can be scientific in its rigour. To expect the law to solely behave as a science, and expect jurisprudence to do the same, misunderstands both 'science' and the role of the law.

One of the tools well suited to such rigour, but generally understood as the exact opposite of science, is classical rhetoric. While many now assume that the art of advocating and persuasion has deserted the corridors of the legal scene, the need for rigorous arguments remain a critical tool of democratic freedom and the quest for true inquiry (see [3]). Classical rhetoric is the area that Könczöl chooses to examine, in order to explore the known as well as the possible Promise of using rhetoric in the field of law. There are two sides in any rhetorical project: analysis and production. In a way, rhetoric invites us, because of its history and its tools, to undertake an ethnomethodological investigation of the law. What is striking about this field is that the ancient canonical texts are, arguably straightforwardly, textbooks. This reminds us of the didactical role of these texts and the didactical role of the law and its study; one relevant not just for jurists, but for society at large. Further, the importance of engagement with the other, either because arguments have been disclosed beforehand or because one has shifted focus in some way to continue the conversation, is one Könczöl is right to draw out attention to.

We find in Könczöl's examination not only different conversational levels and tracks but also levels of story. Following Jackson [7], Könczöl reminds us of the story in the trial and the story of the trial. The addressee of the trial is not singular and certainly not confined to the immediate forensic context. Rhetoric, as Könczöl points out, is largely associated with the pragmatic level of language, with persuasion. How this can be done is influenced by the topics, arguments and even stylistic choices that 
can be made in particular legal contexts. This is a rich and valuable mode of analysis, and one entirely appropriate to legal language, especially because it has its roots in empirical observation, although some may argue that it primarily addresses the question from the binary context of the common law adversarial systems as opposed to the more inquisitorial civil law systems. Nonetheless, exploring rhetoric has important historical dimensions allowing a diachronic conversation, as well as encouraging dialogue across conventional disciplinary boundaries.

A historical strand can also be traced in the tantalizing theory of memes that Gray describes and traces in the work of Balkin. The recursive and iterative link between people, nature and culture, over the course of history is itself emblematic of the Promise of legal semiotics. Semiotics provides a unique entrée into the cultural grounding and evolution of the law. The links with rhetoric and science are also clear. One of Gray's explicit aims, to pass on the theory, in a thoroughly memetic way, resonates with the spirit of the International Roundtable and to borrow Montesquieu's metaphor, the spirit of the law, thus bringing the argument of semiosis into the realm of the practical and the ethical.

Gray notes that memetic theory is "not teleological, but simply responsive to the problems it encounters, with whatever resources it has". While "cultural evolution is more Lamarckian (variation occurs in response to environment) than Darwinian (variation is random, and environment weeds our maladaptions)", the way individuals see the 'same' environment differs. Were this not so, rhetoric would have nothing to teach us about argument construction, engaging with philosophical tradition would be pointless, memes would be copied exactly.

In the next essay, Malik Bozzo-Rey considers how recent academic work on Bentham's theory of language highlights its role and influence on the general theory of law, stressing the relevance of Bentham's studies in today's debate about law. Partially influenced by D'Alembert and Locke, Bentham can be viewed, from a social scientist perspective, as a codifier advocating linguistic reforms (see [11]), including the demystification and clarification of the language of the law.

Using the Monograph as the basis of his analysis, and more precisely the linguistic games it raises, Bozzo-Rey cogently argues that the relationship between law and language-viewed as written systems-provides for the argument that Bentham's work on language should be regarded, first, as an integral part of his work on law; and second as a vision of law as a system of social control. Yet, if the Promise of legal semiotics were to be fulfilled, we can argue that Bozzo-Rey has yet to fulfill the Promise, in other words to critically engage with why, precisely, Bentham's observations on the liaison dangeureuse between law and language are relevant to today's debate about law, taking into account the political and cultural value of any given legal system.

International law plays an important role in fulfilling the Promise of international justice and the various normative conceptions of world order. Koskenniemi $[14$, p. 568] believes that international law should be examined "as a language" and merely not "like a language". He further suggests that "international legal discourse presents a unified structure of argument [... revealing] a particular conception about the relationship between social description and political prescription" (ibid, p. 4), a point which Fikfak and Burnett tacitly imply. The language of international law is 
viewed as a "pre-existing language" expressive of a "pre-existing system of interpreting the world", which 'politicizes' the law while " "equally' legalising politics" (ibid, pp. 12, 13). This allows for a conception of international law as a system of complex legal practices communicating the aporia of the various social systems it is made of.

Fikfak and Burnett examine the interaction between international and domestic law, employing Fish's concept of interpretative communities and reader-response theory. Framing their argument with allusions to existentialism, they critique the undermining of separation of powers with respect to the Executive and Judiciary in the United States. This is a timely paper, and one that can be understood as connecting the semiotics of law to the emergent field of semio-ethics. Such an approach has much promise, especially in the recuperation of what is often seen as the nihilism and political quietism at the heart of contemporary epistemological theory.

\section{Conclusion}

Considering the articles of the Special Issue together with individual perceptive processes in mind is productive. Indeed, it calls to mind Hahlweg and Hooker's [5] evolutionary epistemology. They argue, following evolutionary models, that if there can be no perfect solution-if our telos cannot be certainty-then, we are well advised to maximise the analytic tools available to us. This is appropriate in any number of contexts, but never more so than in relation to the law. Legal systems, while mandating certainty synchronically, also accommodate change, shift and revision diachronically. Sousa e Brito deals explicitly with the question of whether jurisprudence is a science. It is clearly a topic that Gray's work also raises.

Even in these postmodern, deconstructive, cannibalistic times, the spectre of science still looms large. This is surprising, especially given the decades since Kuhn's Structure of Scientific Revolutions [15]. For our purposes, Kuhn's argument that paradigmatic shifts in science are primarily rhetorical is apposite. It may also be appropriate, here, to recall the distinction that Harré makes between scientific and scientistic rhetoric. In the former, "the terminology and the general form of the discourse is the way it is because of certain features of the activities of the community of scientists", while the latter uses the forms of scientific rhetoric without the corresponding scientific activities [6, p. 180]. We do not suggest that our enterprise is not worthwhile, rigorous or without merit, but it is well to remember that it is not a natural science. Memes are not genes. Our methods and aims, while analogous, are distinct.

The question we need to ask ourselves, here, is what do we mean by science? For semiotics at least, it must signify that we undertake our analysis with rigor, clarity and a civilized palate, as Sousa e Brito does. Indeed, it is arguable that deconstruction is what some used to call close reading, or, indeed, careful analysis taking into account broader contexts and questions. It is abundantly clear that the law is rhetorical; it is a recurring topic of analysis and instruction in rhetorical texts. At least in the common law tradition, persuasion rather than proof is salient. 
Burdens and standards of proof are not expressed in statistical matrices, but rather in terms of linguistic modality.

The issue of civilization in respect of analysis is, perhaps, another way of thinking about other questions. While justice is always to come, while the Promise remains to be fulfilled, while methodologies are not answers, but rather tools, while rhetoric and memes are agnostic with respect to right and wrong, at the heart of our enterprise should be ethics, or at least good manners. Fortunately, the International Roundtables are civilized events. The engagement that takes place between disciplines, languages, semiotic theories and topics is valuable. Here, semiotics and law stand at a point of balanced reciprocity where neither discipline is subordinate to the other. Law benefits from the theoretical grounding of other sciences as well as the semiosis attached to them (see for example jurimetrics). The theoretical and practical benefits of semiotics to the law are the refinement of critical legal concepts and legal reasoning.

It may be the case though that we do not have to argue that we are a science to be worthwhile. The communicative rationality [4] in the conversations that the International Roundtables encourage nurtures the interdisciplinary nature of legal semiotics and our humanity.

\section{References}

1. Balkin, Jack M. 1991. The promise of legal semiotics. University of Texas Law Review 69: 1831-1852.

2. Freeman, Michael. 1998. Law and science: Science and law. In Science in court, ed. Freeman Michael, and Reece Helen. Darthmouth: Ashgate.

3. Gleeson, Justin T., and Ruth C.A. Higgins. 2008. Rediscovering rhetoric. Law, language and the practice of persuasion. Annandale: The Federation Press.

4. Habermas, J. 1987. The theory of communicative action. Volume 2: Lifeworld and system a critique of functionalist reason. Boston: Beacon Press.

5. Hahlweg, Kai, and Alan Hooker (eds). 1989. Issues in evolutionary epistemology. New York: SUNY Press.

6. Harré, Rom. 1985. Situational rhetoric and self-representation. In Language and social situations, ed. Joseph P. Forgas, 175-188. New York: Springer-Verlag.

7. Jackson, Bernard. 1988. Law, fact and narrative coherence. Liverpool: Deborah Charles Publications.

8. Jackson, Bernard. 1995. Making sense in law. Linguistic, psychological and semiotic perspectives. Liverpool: Deborah Charles Publications.

9. Jackson, Bernard. 1996. Making sense in jurisprudence. Liverpool: Deborah Charles Publications/ London: Routledge.

10. Jeremy, Paul. 1991. The politics of legal semiotics. Texas Law Review 69: 1779-1829.

11. Kayman, Martin A. 2004. A memorial for Jeremy Bentham: Memory, fiction, and writing the law. Law and Critique 15 (3): 207-229.

12. Kennedy, Duncan. 1994. A semiotics of legal argument. In Collected courses of the Academy of European law, vol. III, book 2, ed. Academy of European Law, 309-365. Netherlands: Kluwer.

13. Kevelson, Roberta. 1988. The law as a system of signs. Netherlands: Springer.

14. Koskenniemi, Martti. 2005. From apologia to Utopia. The structure of international legal argument. Cambridge: Cambridge University Press.

15. Kuhn, T.S. 1962. The structure of scientific revolutions, 1st ed. Chicago: University of Chicago Press.

16. Sykes, Geoffrey. 2008. "A short genealogy of realism": Peirce, Kevelson and legal semiotics. International Journal for the Semiotics of Law 21 (2): 103-116. 